12. Babkin A.I., Sanfirov I.A., Macharet A.M. Estimation of information content of mine multi-wave seismic survey for prediction of variability of physical and mechanical properties of rock mass // 16th Conference and Exhibition Engineering and Mining Geophysics 2020. - Perm, 2020. - P.

13. Никитин В.Н. Основы инженерной сейсмики. - М.: Изд-во МГУ,1981. - 176 с.: ил.

14. Puzyrev N.N. Methods and objects of seismic investigations. Introduction to general seismology. - Novosibirsk: Geo, 2004. -281 p.

15. Пузырев Н.Н., Бобров Б.А., Гик Л.Д., Тригубов А.В. Исследование направленности источников поперечных сейсмических волн средствами физического моделирования // Геология и геофизика. 1985. - Т. 26, № 5. - С. 66-75.

16. Савич А.И., Коптев В.И., Никитин В.Н., Ященко З.Г. Сейсмоакустические методы изучения массивов скальных пород. - М.: Недра, 1969. - 239 с.: ил.

УДК:550.34

DOI:10.7242/echo.2020.4.13

\title{
СЕЙСМИЧЕСКАЯ АКТИВНОСТЬ ЗАПАДНО-УРАЛЬСКОГО РЕГИОНА И СЕЗОННЫЕ ВАРИАЦИИ СКОРОСТИ ВРАЩЕНИЯ ЗЕМЛИ
}

\author{
Л.В. Некрасова \\ Горный институт УрО РАН, г. Пермь
}

\begin{abstract}
Аннотация: Неравномерность суточного вращения Земли вокруг своей оси оказывает непосредственное влияние на геодинамические процессы, происходящие в земной коре.

Нами впервые был проведен детальный анализ сезонной структуры сейсмических процессов на территории ряда месторождений на различных масштабных уровнях. Это стало возможно благодаря богатому накопленному материалу, который содержат многолетние каталоги сейсмических событий на различных месторождениях.

В данной статье представлены исследования сезонных особенностей техногенных сейсмических процессов на примере Верхнекамского месторождения полезных ископаемых. Было проанализировано более 13 тысяч сейсмических событий с энергией от 1 Дж до 100 тыс. Дж за 24-летний период с 1995 по 2019 год. В результате исследований было выявлено, что реализация событий для Верхнекамского месторождения калийно-магниевых солей происходит по определенным временным законам. Выделены циклы активизации событий, очаги которых с высокой корреляционной связью реагируют на различные компоненты скорости вращения Земли. Определены периоды времени наиболее высокой сейсмической активности для данного месторождения.
\end{abstract}

Ключевые слова: сейсмическая активность, изменения скорости вращения Земли, ЗападноУральский регион, Верхнекамское месторождение калийных солей.

Неравномерность суточного вращения Земли вокруг своей оси оказывает непосредственное влияние на геодинамические процессы, происходящие в земной коре. На это указывают многие ученые и исследователи: Б.Л. Личко, В.П. Сайгак, М.В. Стовас, Н.И. Николаева и другие.

До 1955 года сведения о неравномерности вращения Земли получали астрономическим и геодезическим методами. С 1955 года для этих целей используют атомные часы. Неравномерность вращения Земли по современным представлениям слагается из трех компонент: вековой, периодической (регулярной) и нерегулярной (непериодической). Регулярные изменения скорости в свою очередь делятся на долгопериодические, сезонные и короткопериодические. Из регулярных вариаций скорости вращения наиболее хорошо изучены в настоящее время сезонные колебания. Итак, скорость суточного вращения Земли бывает максимальной в начале августа. Второй максимум, меньший, чем в июле-августе, имеет место в начале февраля. Минимальные значения скорости наблюдаются в апреле и ноябре. Обычно сезонные колебания длительности суток при- 
нято аппроксимировать суммой годовой и полугодовой гармонических компонент. Амплитуды и фазы сезонных волн меняются от года к году. Спектральный анализ изменений среднемесячных значений амплитуд годовой и полугодовой волн обнаружил в этих изменениях гармоники, близкие к 11, 6, 3, 4 и 2 годам.

Нами выполнены исследования сезонных особенностей техногенных сейсмических процессов на различных месторождениях, расположенных в Западном Урале и Сибири.

В данной статье рассмотрены результаты анализа сейсмической активности на примере Верхнекамского месторождения калийных солей (ВКМКС). На данном месторождении в течение четверти века проводились непрерывные сейсмологические наблюдения. Были сформированы уникальные базы сейсмологических данных. Наличие таких баз делает этот горнодобывающий бассейн уникальным объектом для изучения особенностей сейсмического режима в условиях сильного техногенного воздействия на недра и для анализа возможного влияния различных природных факторов.

Исследования показали, что слабая сейсмичность (микросейсмичность) Верхнекамского месторождения калийных солей подчиняется определенным временным закономерностям в циклах своей активизации в течение года. Сравнение распределения по месяцам всех динамических событий с параметрами ротационного режима указывает на наличие устойчивой корреляционной связи между двумя процессами.

Разработка Верхнекамского месторождения производится в три смены в течение суток. При этом число сейсмических событий в интервалах производственных работ сильно возрастает по сравнению с интервалами времени, когда эти работы не выполняются. События, приуроченные к максимумам, отнесены нами к «условно техногенным», а события, произошедшие в оставшееся время, к «условно природным».

Благодаря накопленному богатому материалу, который содержат многолетние каталоги сейсмических событий, впервые был проведен детальный анализ сезонной структуры сейсмических процессов на территории месторождения на различных масштабных уровнях.

Слабая сейсмичность Верхнекамского месторождения представляет собой более 13000 динамических явлений, зарегистрированных с апреля 1995 по апрель 2019 года, и имеет свой сезонный характер проявления. Для него характерна связь в реализации динамических явлений в энергетическом диапазоне от 1 Дж до 100000 Дж с вариациями скорости вращения Земли.

Нами проанализировано количество сейсмических событий в месяц $(N)$, сейсмическая энергия, выделенная в течение месяца $(E)$ и средняя сейсмическая энергия $(E / N)$.

Проведенные исследования выявили, что весь диапазон сейсмических событий Верхнекамского месторождения калийных солей от 3 Дж до 30000 Дж прекрасно реагирует на изменения скорости (рис. 1) и ускорения вращения Земли (рис. 4). Коэффициент корреляции $K$ для всех сейсмических событий варьирует от 0,61 до 0,75 и 0,79, соответственно. Для «условно техногенных» событий (рис. 6, рис. 8) коэффициент корреляции $K$ несколько выше, чем для «условно природных», и изменяется в пределах от 0,64 до 0,79. Для «условно природных» - от 0,62 до 0,73 (рис. 9). Исключение составляют события, лежащие в диапазоне от 1000 Дж до 3000 Дж, для которых коэффициент корреляции снижается до $0,60,0,59$ и 0,55 , соответственно. Особенно высокий коэффициент корреляции $K=0,79$ отмечен для наиболее сильных «условно техногенных» сейсмических событий с энергией от 3000 до 30000 Дж и событий от 100 до 300 Дж (рис. 1).

Таким образом, реализация всех сейсмических событий Верхнекамского месторождения калийных солей с энергией от 3 Дж до 30000 Дж связана с изменениями скорости вращения Земли (рис. 10) и наиболее активно происходит в весенне-осеннее время - тогда, когда скорость вращения Земли минимальна. Сейсмическая активность снижается 
в мае-июне, августе и феврале, когда скорость вращения Земли возрастает. Период повышенной сейсмической активности на Верхнекамском месторождении отмечается с марта по апрель месяцы и с сентября по ноябрь. Наибольшее число сейсмических событий произошло в марте (максимум) и ноябре. Так же проявляются во времени «условно природные» события. Наибольшее число «условно техногенных» (рис. 11) сейсмических событий происходит в марте-апреле и октябре-ноябре месяцах, их максимум отмечается в марте и ноябре.

Коэффициенты корреляции $K$ изменений скорости вращения Земли и энергии $E$, выделенной в течение месяца на Верхнекамском месторождении калийных солей (рис. 2, рис. 5), варьируется в пределах от 0,66 до 0,77 для всего диапазона сейсмических событий с энергией от 1 Дж до 30000 Дж, для «условно техногенных» (рис. 7) сейсмических событий - от 0,66 до 0,80 , для «условно природных» событий - от 0,60 до 0,74. Коэффициент корреляции К немного снижен для событий с энергией от 1000 Дж до 3000 Дж. Для наиболее сильных «условно техногенных» сейсмических событий в диапазоне от 3000 Дж до 30000 Дж коэффициент корреляции $K$ увеличивается и составляет 0,78 (рис. 7). Как и для событий от 100 до 300 Дж (К равен 0,79).

Наибольшее количество энергии, порядка 1,3 млн. Дж, выделено при реализации всех сейсмических событий в диапазоне от 3 Дж до 30000 Дж в ноябре месяце. Следующий экстремум отмечен в марте, когда выброс энергии составил более 1 млн. Дж (рис. 10). При проявлении «условно техногенных» сейсмических событий также наибольшее количество выделенной энергии отмечено в марте-апреле и октябреноябре (рис. 11). Максимальный выброс сейсмической энергии наблюдается в ноябре, следующий за ним - в марте месяце.

Влияние полугодовой составляющей скорости вращения Земли выявлено на группу сейсмических событий Верхнекамского месторождения калийных солей, лежащих в диапазоне от 10 Дж до 100 Дж (рис. 3). Коэффициент корреляции $K$ составляет 0,74 как для общего числа событий $N$, так и для сейсмической энергии $E$, выделенной в течение месяца.

Период активизации микросейсмического процесса в данном энергетическом диапазоне отмечен в марте-апреле и сентябре-октябре с максимумом проявления сейсмической активности в марте месяце, следующий по величине экстремум приходиться на октябрь (рис. 12).

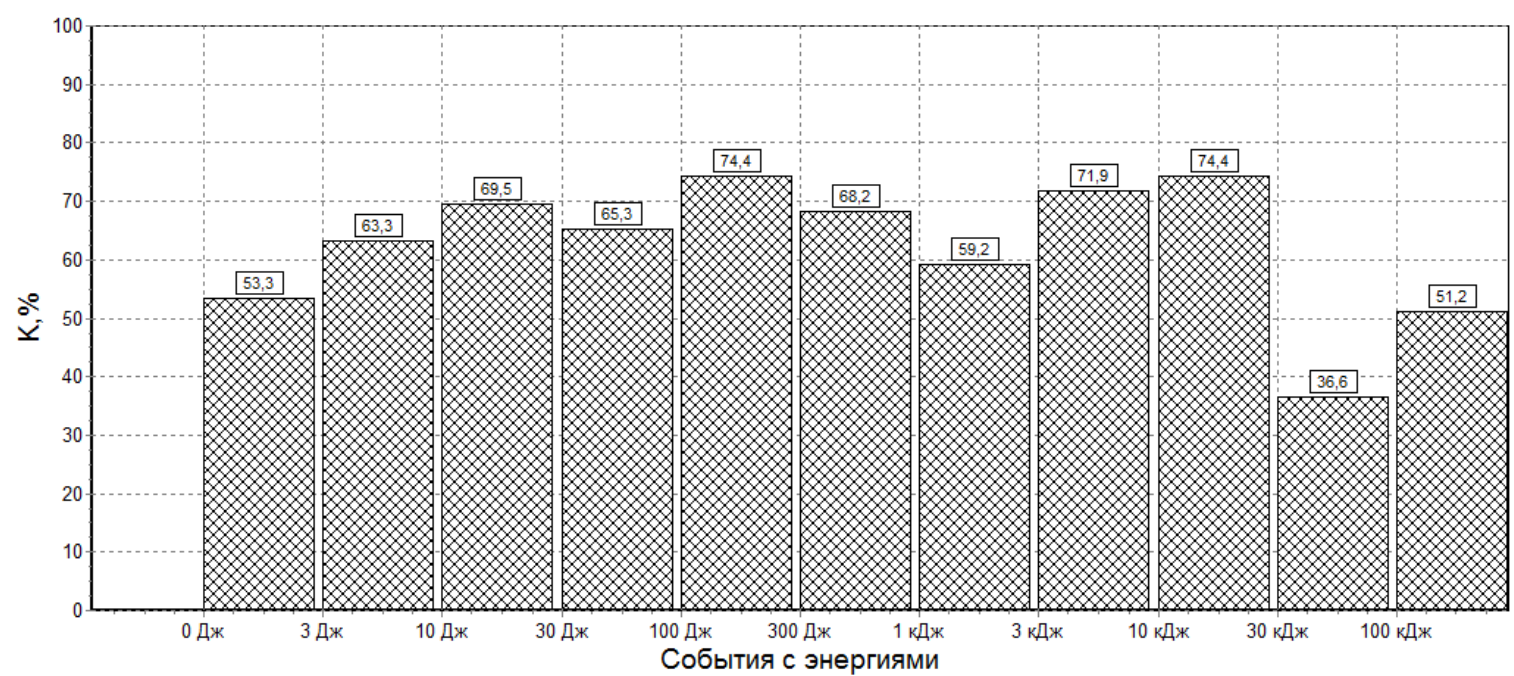

Рис. 1. Модули коэффициентов корреляции функции сезонных изменений скорости вращения Земли с сейсмическими явлениями различного энергетического уровня Верхнекамского месторождения калийных солей за период с 1995 по 2019 год 


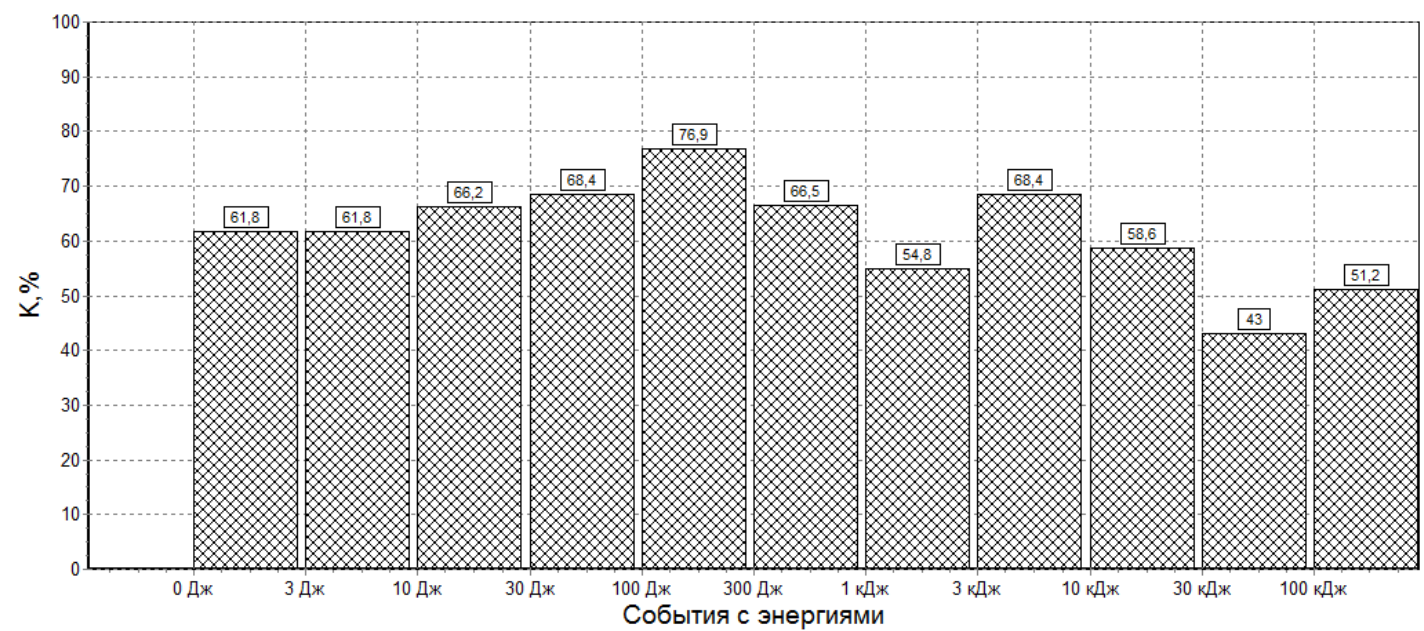

Рис. 2. Модули коэффициентов корреляции функции сезонных изменений скорости вращения Земли и сейсмической энергией, выделенной в течение месяца событиями различного энергетического уровня для Верхнекамского месторождения калийных солей за период с 1995 по 2019 год

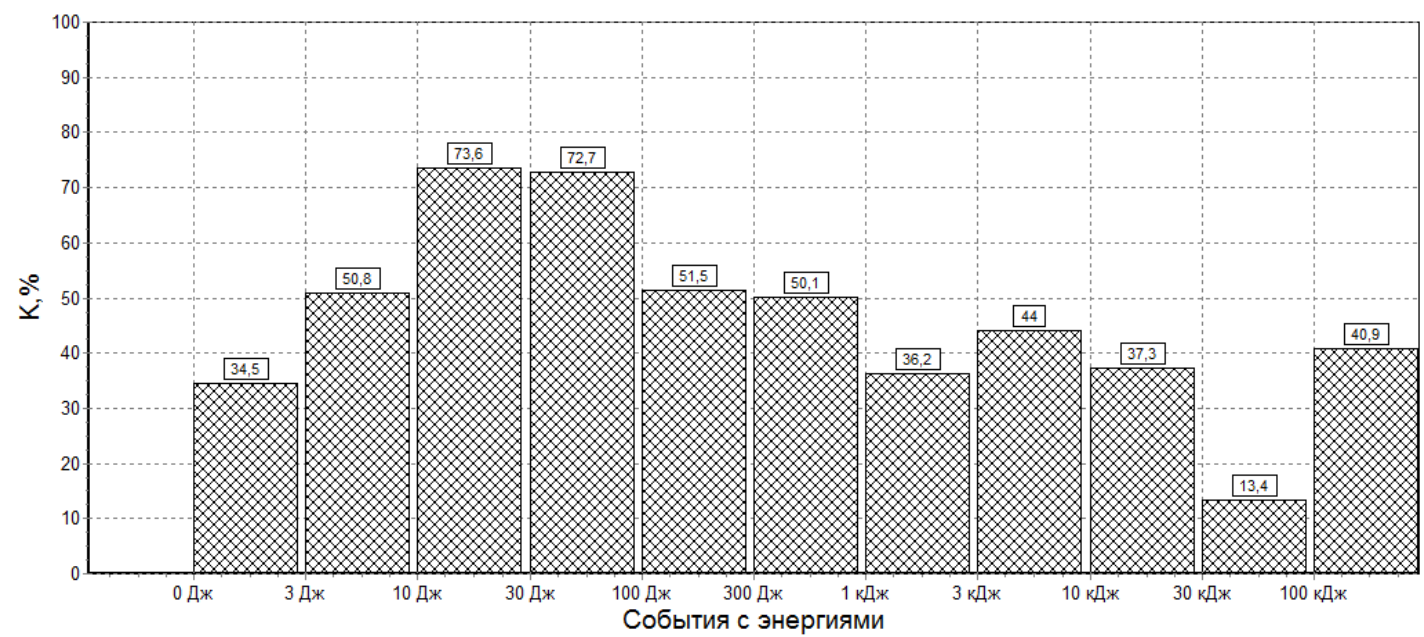

Рис. 3. Модули коэффициентов корреляции полугодовой составляющей сезонных изменений скорости вращения Земли с сейсмическими явлениями различного энергетического уровня Верхнекамского месторождения калийных солей за период с 1995 по 2019 год

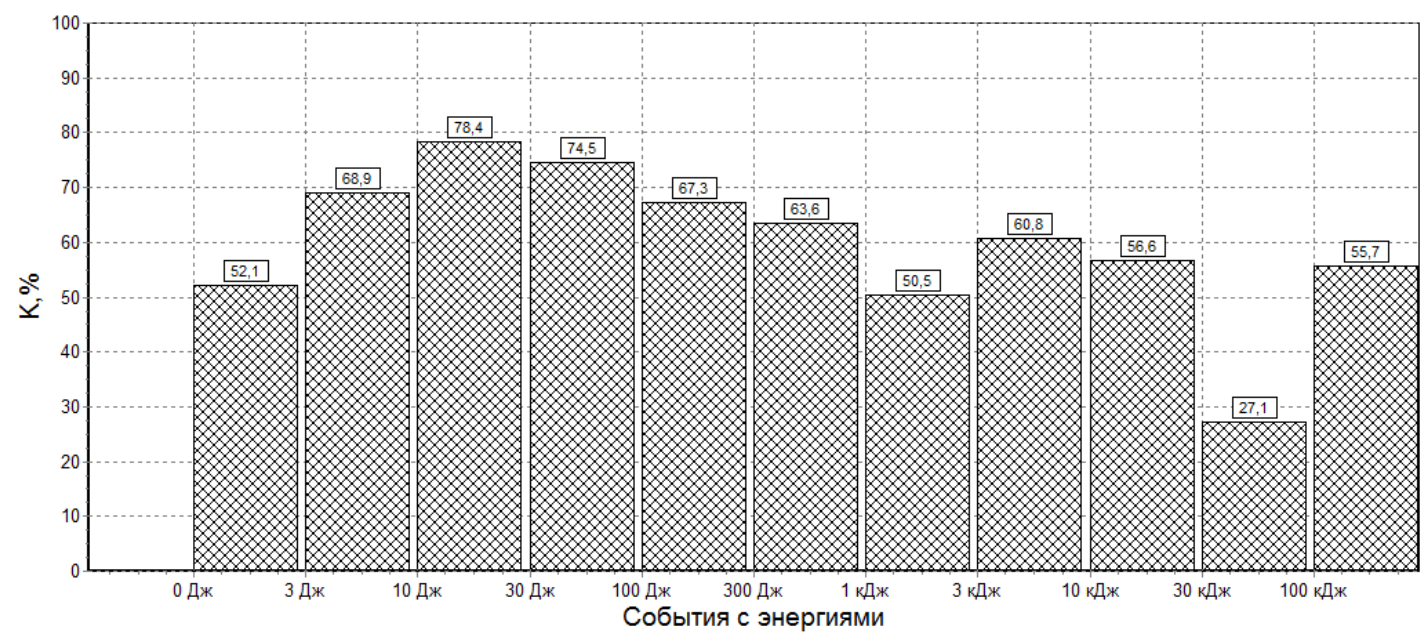

Рис. 4. Модули коэффициентов корреляции ускорения вращения Земли и сейсмическими явлениями различного энергетического уровня Верхнекамского месторождения калийных солей за период с 1995 по 2019 год 


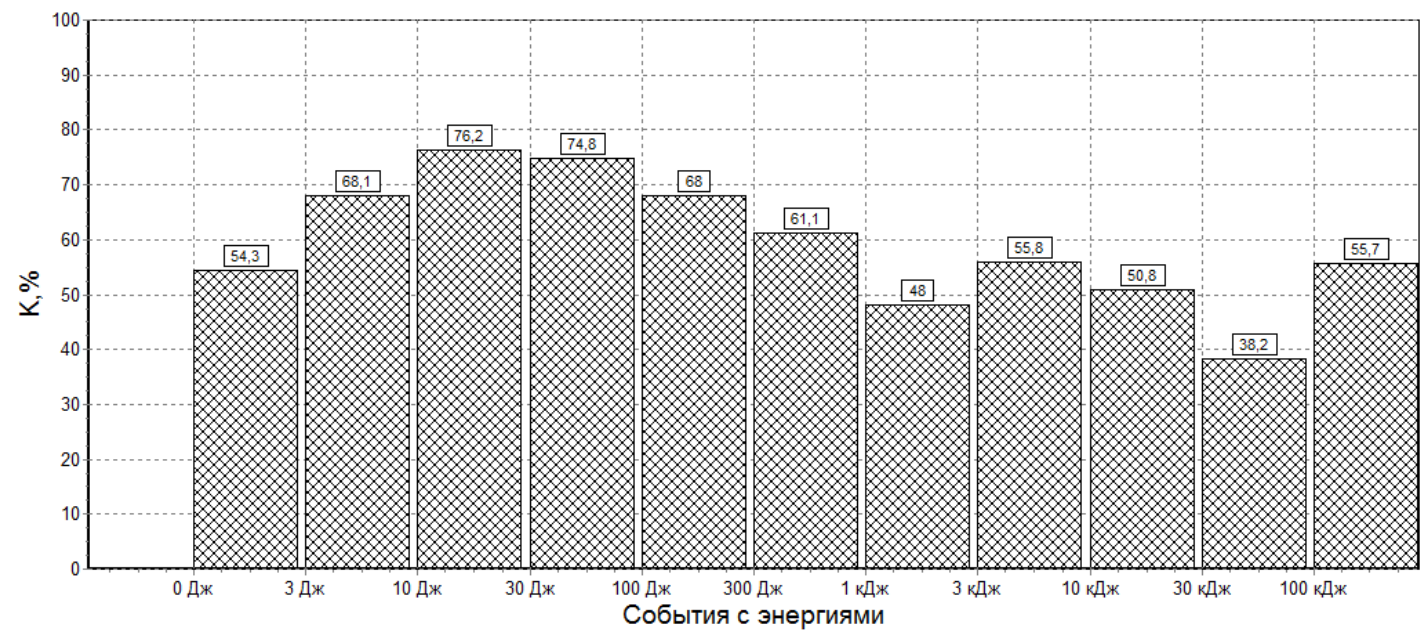

Рис. 5. Модули коэффициентов корреляции ускорения вращения Земли и сейсмической энергией, выделенной в течение месяца событиями различного энергетического уровня Верхнекамского месторождения калийных солей за период с 1995 по 2019 год

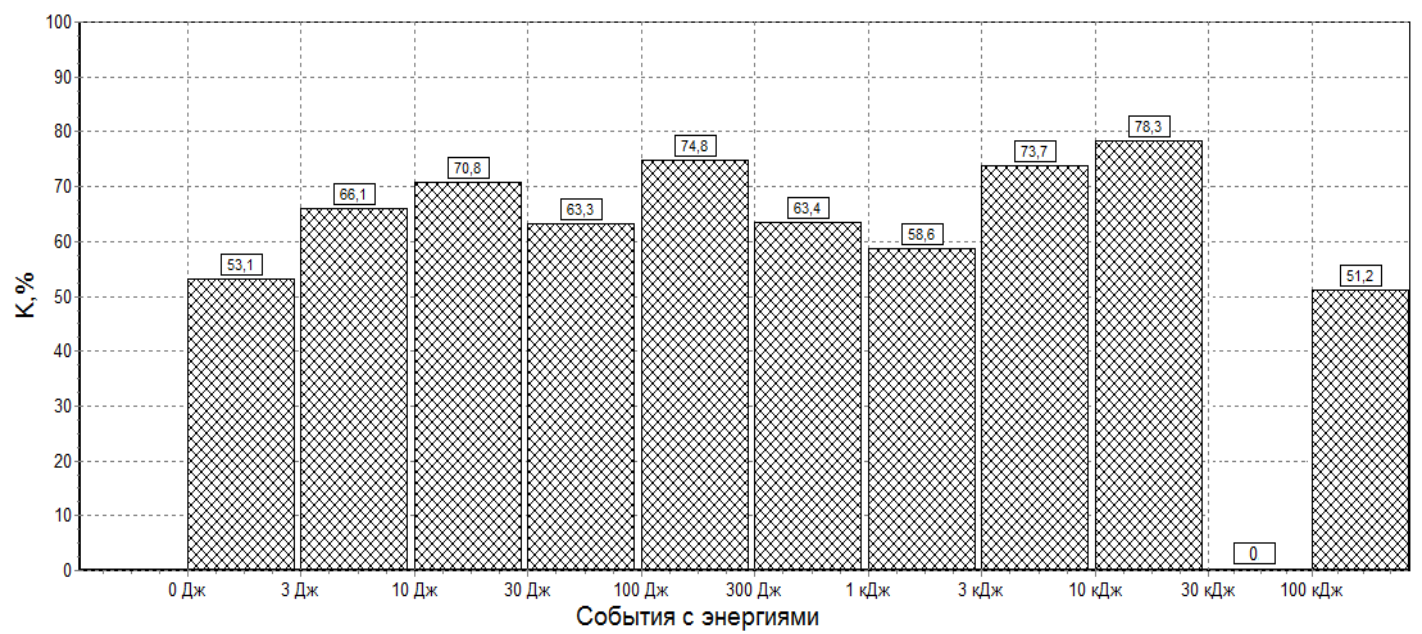

Рис. 6. Модули коэффициентов корреляции функции сезонных изменений скорости вращения Земли с «условно техногенными» сейсмическими явлениями различного энергетического уровня для Верхнекамского месторождения калийных солей за период с 1995 по 2019 год

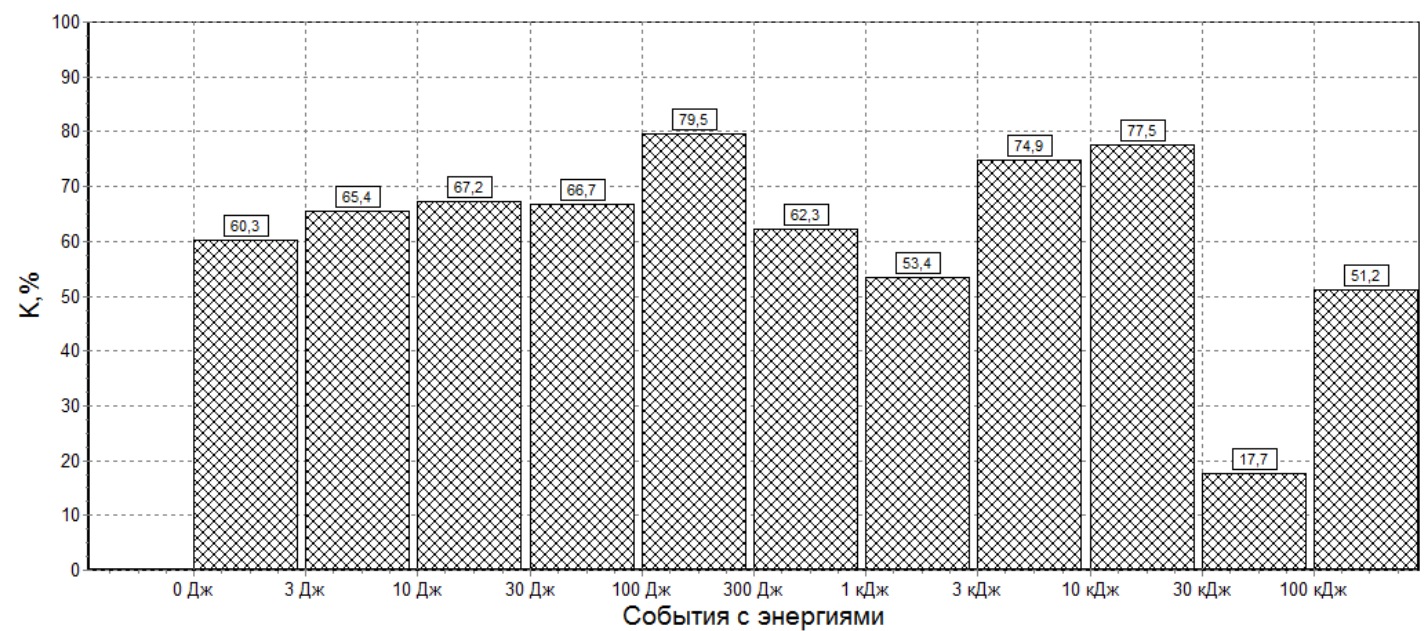

Рис. 7. Модули коэффициентов корреляции функции сезонных изменений скорости вращения Земли с сейсмической энергией, выделенной в течение месяца «условно техногенными» событиями различного энергетического уровня на Верхнекамском месторождении калийных солей за период с 1995 по 2019 год 


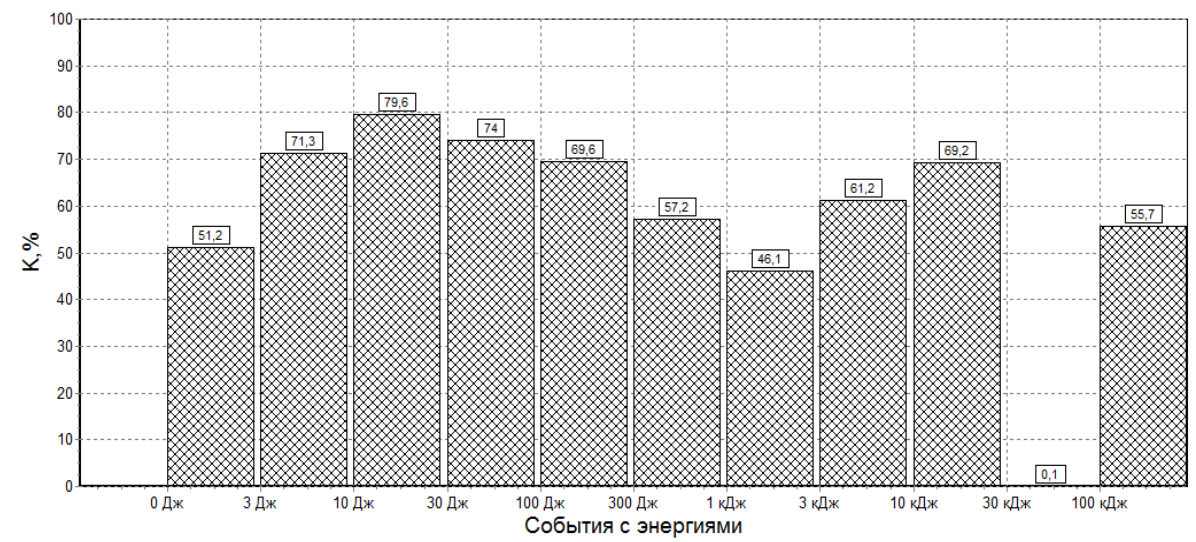

Рис. 8. Модули коэффициентов корреляции ускорения вращения Земли с «условно техногенными» сейсмическими событиями различного энергетического уровня на Верхнекамском месторождении калийных солей за период с 1995 по 2019 год

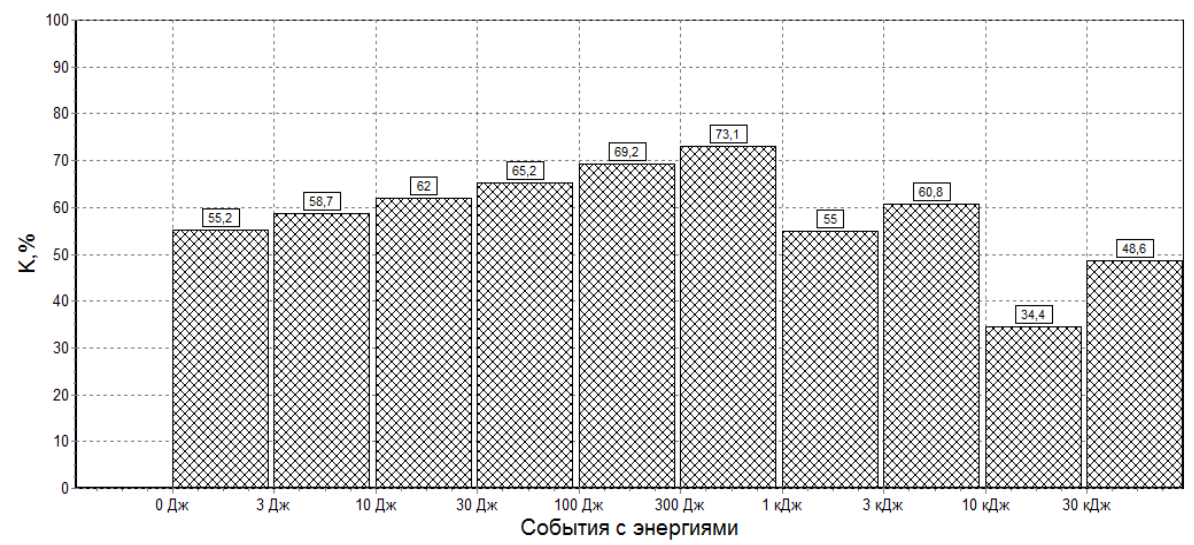

Рис. 9. Модули коэффициентов корреляции функции сезонных изменений скорости вращения Земли с «условно природными» сейсмическими явлениями различного энергетического уровня для

Верхнекамского месторождения калийных солей за период с 1995 по 2019 год

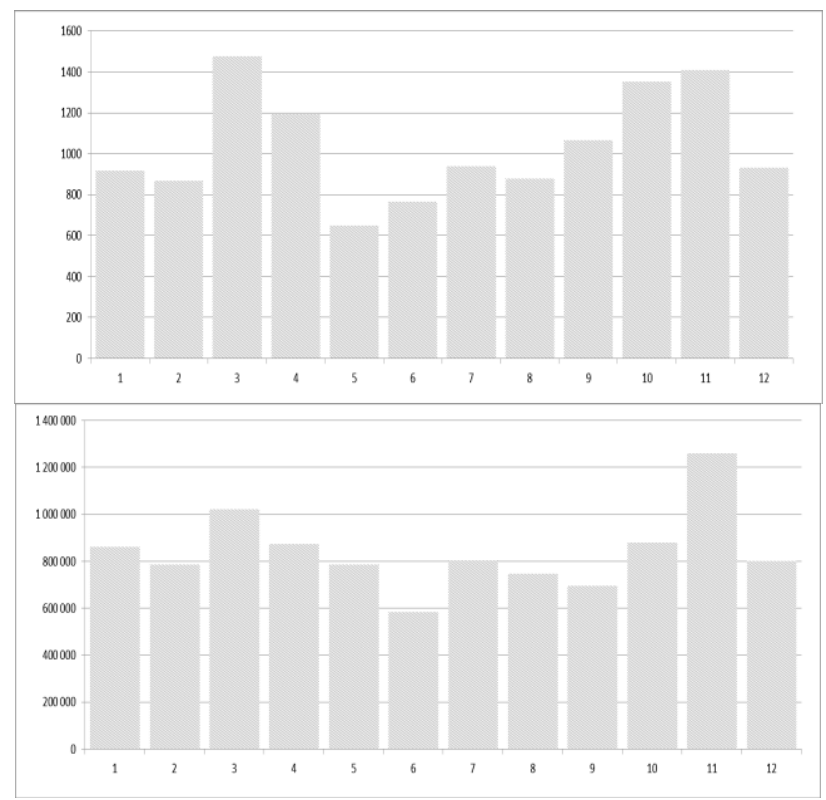

Рис. 10. Распределение по месяцам года сейсмических событий с энергией от 3 Дж до 30000 Дж (слева) и сейсмической энергии, выделенной в течение месяца при реализации событий в данном диапазоне (справа) на Верхнекамском месторождении калийных солей за период с 1995 по 2019 год 


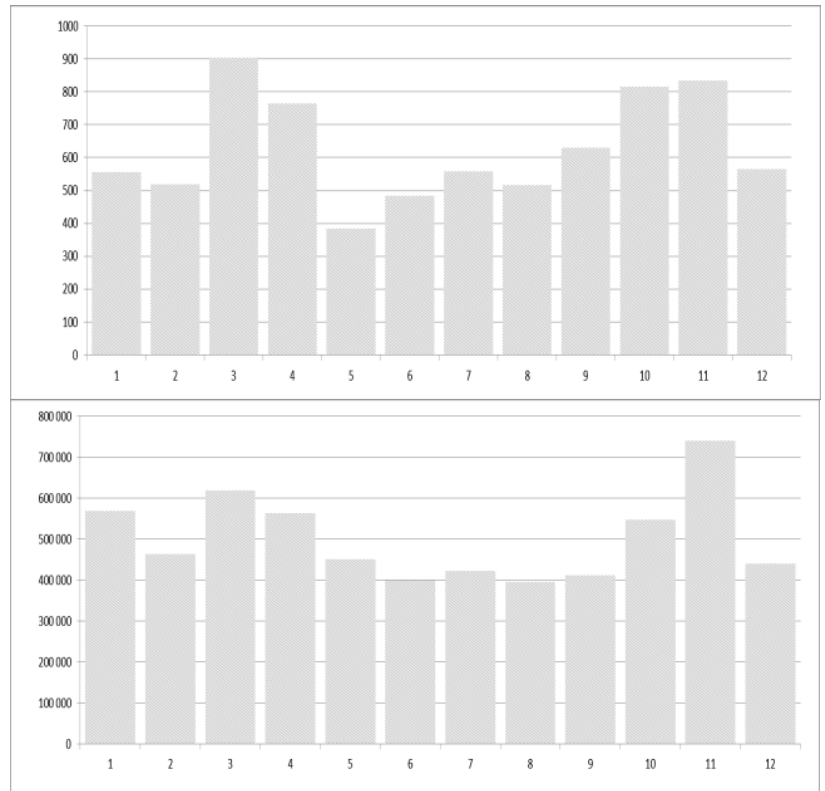

Рис. 11. Распределение в течение года «условно техногенных» сейсмических событий с энергией от 3 Дж до 30000 Дж (слева) и сейсмической энергии, выделенной в течение месяца при реализации событий в данном диапазоне (cnpaвa) на Верхнекамском месторождении калийных солей за период с 1995 по 2019 год

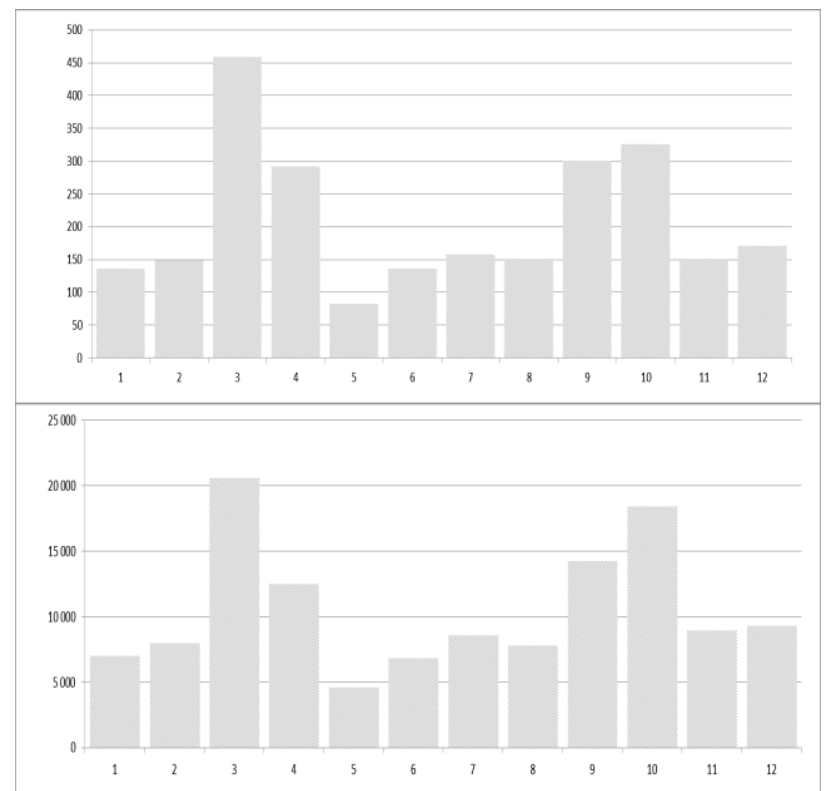

Рис. 12. Распределение по месяцам года сейсмических событий с энергией от 10 Дж до 100 Дж (слева) и сейсмической энергии, выделенной в течение месяца при реализации событий в данном диапазоне (справа) на Верхнекамском месторождении калийных солей за период с 1995 по 2019 год

Итак, выполненные исследования свидетельствуют о существовании четко выраженной сезонной структуры микросейсмического процесса. Важно отметить, что эффект неравномерного вращения Земли наиболее рельефно проявляется для событий определенных энергетических уровней. Если при анализе событий не учитывать их масштабный уровень, то взаимосвязь между двумя процессами в ряде случаев получить весьма проблематично.

Проведенное нами сравнение распределений сейсмичности в течение года для Верхнекамского месторождения калийных солей с сезонными вариациями скорости суточ- 
ного вращения Земли показывает, что сейсмическая активность существенно возрастает в периоды замедления вращения Земли. Поскольку при уменьшении скорости вращения энергия вращающегося тела становится меньше, то разность энергий может высвобождаться, в том числе в виде сейсмических событий.

Исследование выполнено при финансовой поддержке Программы ФНИ, проект № 0422-2019-0146-С-02 (регистрачионный номер темы НИОКТР: AAAA-A18-118040690028-5)

\title{
БИБЛИОГРАФИЧЕСКИЙ СПИСОК
}

1. Киселев В. М. Неравномерность суточного вращения Земли / отв. ред. Ю.Д. Калинин. - Новосибирск: Наука, 1980. - С. 160.: ил.

2. Сидоренков Н.С. Физика нестабильностей вращения Земли - М.: Наука, Физматлит, 2002. - 380 с.: ил. - С. $15,112,159,346-349$.

\section{ТЕХНОГЕННЫЕ ПОМЕХИ ПРИ ВЫПОЛНЕНИИ МАГНИТОРАЗВЕДОЧНЫХ РАБОТ}

\author{
П.Н. Новикова \\ Горный институт УрО РАН, г. Пермь
}

\begin{abstract}
Аннотация: Рассматриваются основные типы техногенных помех при исследованиях методом магниторазведки. Обсуждаются вариации магнитного поля в пределах городских и промышленных территорий. Приведены практические примеры, демонстрирующие характер магнитного поля вблизи подземных коммуникаций, высоковольтных линий электропередач, локальных технических объектов. Предложены методы фильтрации и разделения техногенных помех разных типов.

Ключевые слова: техногенные помехи, магниторазведка, EMD-разложение, техногенный объект, фильтрация, статистическая трансформация.
\end{abstract}

\section{Введение}

Задача обнаружения и локализации техногенных и археологических объектов методом магниторазведки не теряет своей актуальности в наземных, гидромагнитных и беспилотных исследованиях. При производстве таких магниторазведочных работ традиционно различают помехи геологического и негеологического происхождения. Геологические помехи, например, могут быть связаны со сложно намагниченным геологическим разрезом, в котором расположены искомые объекты [5]. Помехи негеологического генезиса можно условно разделить на переменные и постоянные [6, 8]. Помехи переменного типа могут представлять из себя или электромагнитное излучение, источниками которого являются различные линии электропередач, или импульсные помехи от движущегося транспорта, трамвайных и ж/д путей и т.д. Помехи постоянного типа вызваны подземными и наземными магнитными объектами.

\section{Вариации магнитного поля урбанизированных территорий}

Наличие техногенных помех в полевых данных напрямую зависит от количества и удаленности источников электромагнитного излучения. Средняя интенсивность поме- 